\title{
Archaeomagnetic study of a limekiln in the Les Ferreres Roman aqueduct, World Heritage Site of Tarraco
}

\author{
Lluís Casas ${ }^{1}$ (D) C Carlota Auguet ${ }^{2} \cdot$ Núria Guasch-Ferré $^{3} \cdot$ Miriam Gómez-Paccard $^{4}$ - José Luís Prada ${ }^{5}$. \\ Àfrica Pitarch Martí ${ }^{6} \cdot$ Marta Badia $^{1} \cdot$ Jorge Sanjurjo-Sánchez $^{7} \cdot$ Moisés Díaz $^{8} \cdot$ Joan Menchon $^{9}$
}

Received: 11 February 2020 / Accepted: 5 August 2020

(C) Springer-Verlag GmbH Germany, part of Springer Nature 2020

\begin{abstract}
The aqueduct of Les Ferreres is a major element of the Archaeological Ensemble of Tarraco. Although the ashlars of the aqueduct are stacked without mortar, lime was used in some parts and lime was certainly used in later repairs. Worthy of note is a coating mortar used in a well-documented restoration (1854-1856). In this study, a limekiln found near the Roman aqueduct has been archaeomagnetically dated to determine if it was used for the construction of the aqueduct or in later repairs. The mean values for the measured archaeomagnetic direction from the limekiln were compared with two different archaeomagnetic models (SCHA.DIF.3k and GUMF1), and both indicate that the limekiln is modern with ages only slightly older than the well-documented restoration. The extensive use of the coating mortar in that restoration is consistent with the need of onsite lime production. Additional archaeomagnetic intensity has not contributed to constrain further the obtained archaeomagnetic age but the intensity datum can be added to archaeomagnetic intensity datasets to enhance geomagnetic intensity field models. The paper illustrates how archaeomagnetic dating can be useful to characterize secondary structures of major cultural heritage monuments.
\end{abstract}

Keywords Archaeomagnetism $\cdot$ Dating $\cdot$ Mortar $\cdot$ Geomagnetic field modeling $\cdot$ UNESCO WH List

\section{Introduction}

Monuments are a substantial part of cultural heritage and, as such, need to be preserved for future generations. Conservation and protection policies promoted by both local governments and international institutions are fundamental not only to guarantee their preservation but also to study them

\section{Lluís Casas}

Lluis.Casas@uab.cat

1 Facultat de Ciències, Departament de Geologia, Universitat Autònoma de Barcelona, Campus UAB, 08193 Bellaterra, Catalonia, Spain

2 Departament de Física, Universitat Politècnica de Catalunya (BarcelonaTech), EPSEB, Av. Dr. Marañón, 44-50, 08028 Barcelona, Catalonia, Spain

3 Escola d'Arquitectura La Salle, Universitat Ramon Llull, Carrer de Sant Joan de La Salle, 42, 08022 Barcelona, Catalonia, Spain

4 Instituto de Geociencias (CSIC-UCM), Calle del Doctor Severo Ochoa, 7, Edificio Entrepabellones 7 y 8, 28040 Madrid, Spain from both historical and scientific point of views. Possibly the most internationally recognized mechanism to promote preservation and investment on cultural heritage is inscription on the UNESCO World Heritage (WH) List, which works as a kind of franchise contract between the UNESCO and the States Parties (Adie 2017). For any Cultural Heritage site, but in particular for those ranked as WH monument, there is

5 Escola Superior de Conservació i Restauració de Béns Culturals de Catalunya, Carrer d'Aiguablava, 109-113, 08033 Barcelona, Catalonia, Spain

6 Seminari d'Estudis i Recerques Prehistòriques (SERP), Departament d'Història i Arqueologia, Facultat de Geografia i Història, Universitat de Barcelona, Carrer Montalegre, 6, 08001 Barcelona, Catalonia, Spain

7 Instituto Universitario de Xeoloxía "Isidro Parga Pondal". Edificio Servizos Centrais Investigación, Universidade da Coruña, 15071 A Coruña, Spain

8 Institut Català d'Arqueologia Clàssica, Plaça d'en Rovellat, s/n, 43003 Tarragona, Catalonia, Spain

9 Ajuntament de Tarragona-Museu d'Història de Tarragona, Carrer Cavallers, 14, 43003 Tarragona, Catalonia, Spain 
a need for a continuous research not only on their main elements but also on the side ones that often are considered nonrelevant and are unknown to the main public. Only by performing a rigorous research of the whole ensemble and from different perspectives (i.e., historical, archeological, archaeometric) one will produce reliable knowledge on the monument under study. The present paper represents a case study of archaeomagnetic dating applied to a secondary structure nearby a major heritage monument.

The Archaeological Ensemble of Tarraco located in Catalonia (NE Spain) entered the WH List in 2000. The ensemble groups the existing Roman ruins in the present-day city of Tarragona and a number of elements within the surrounding territory, including the magnificent Les Ferreres aqueduct (Fig. 1), which, as early as 1905, was already declared a National Monument by the Spanish authorities (Gaceta de Madrid 1905). The aqueduct, also called Pont del Diable (Catalan for Devil's bridge), is one of the most well preserved Roman aqueducts. The monument, $217 \mathrm{~m}$ long and with a maximum height of $27 \mathrm{~m}$, consists in two levels of stone arches: The upper section has 25 arches, and the lower one has 11 . The ashlars are, apparently, stacked without mortar (opus quadratum). Historical and archeological interpretations point to the construction of the aqueduct in the first century AD (Macias and Rodà 2015; Mar et al. 2015). There are some hypotheses on ancient restorations of the monument with no evidence at all. To the best of our knowledge, the first well-documented restoration was performed in the midnineteenth century under the supervision of the historian and archeologist Bonaventura Hernández Sanahuja (Hernández
Sanahuja 1867). Later, during the twentieth century, occasional repairs were also conducted and finally an integral restoration funded by the Spanish Ministerio de Fomento and the Tarragona city council was undertaken in 2010-2011 (Adell and Menchon 2011).

The present paper presents the archaeomagnetic dating of the remains of a limekiln found excavated into the ground near the bottom of the Roman aqueduct (Fig. 1), on its northern flank, in order to identify the link between these two constructions. The determination of both the direction and the intensity of the past geomagnetic field magnetically recorded by the kiln and the comparison with the regional secular variation of the Earth's magnetic field in Western Europe will allow us to independently date the studied structure. The study will also contribute to reconstruct a part of the restoration story of this major element of the WH ensemble.

\section{Materials and methods}

\section{The limekiln}

The preserved part of the kiln is a slightly urceolate unlined cylindrical big cavity dug into the ground. The ground is basically a friable Miocene deposit made of intercalation of reef calcarenites and micritic layers. The structure is presently cut longitudinally in such a way that the original supply conduct has been destroyed and now it is easy to enter the cavity (Fig. 1). Small holes towards the upper part of the inner walls indicate the position of the baking rack system. At the

Fig. 1 Location of the sampled kiln (long., $1.24^{\circ} \mathrm{E}$; lat., $41.15^{\circ}$ $\mathrm{N}$ ), general view of the aqueduct, and the sampled kiln with insets showing the cores drilled in the left (L samples) and right ( $\mathrm{R}$ samples) of the kiln

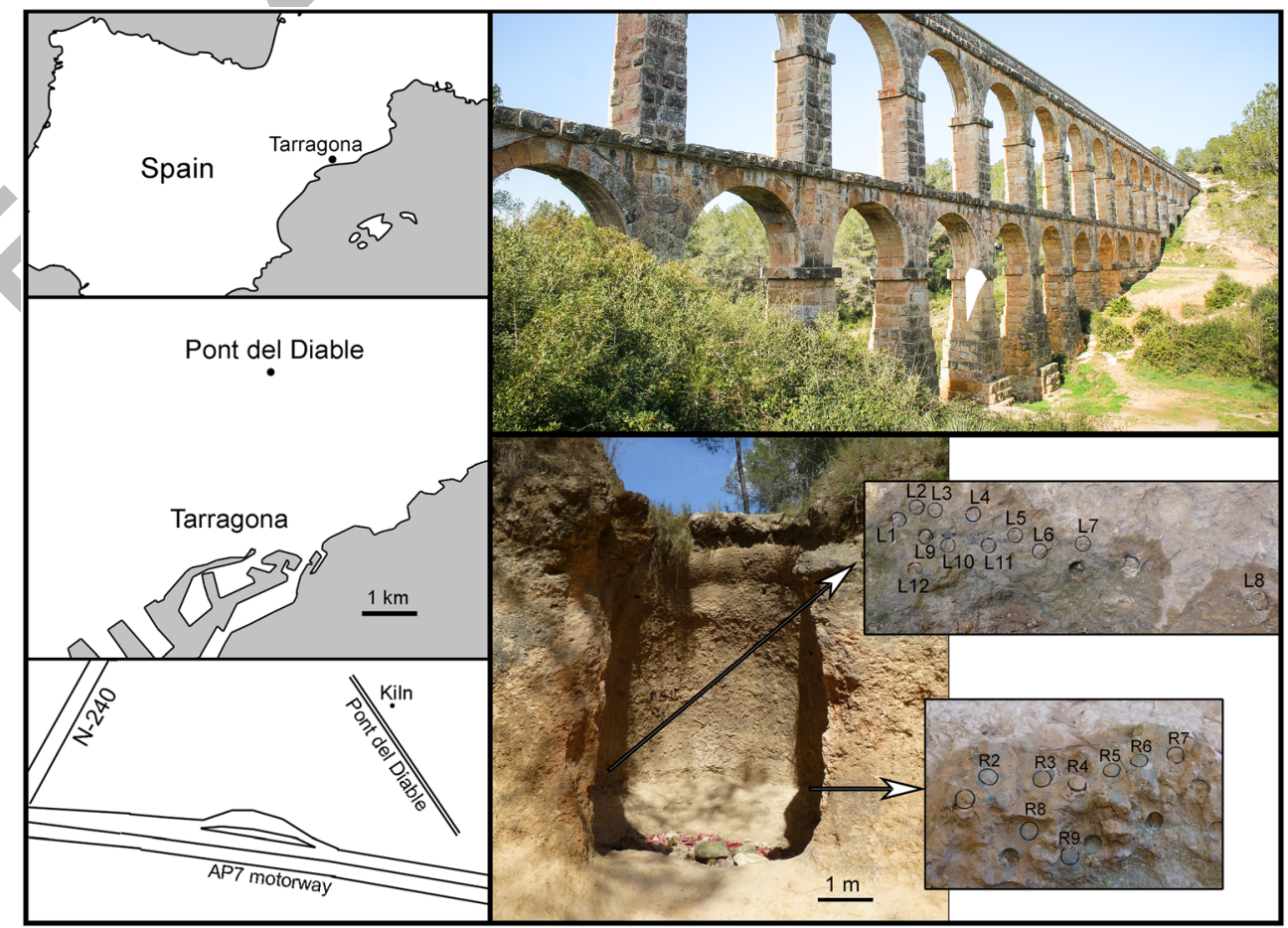


bottom, some slag crusts are observed indicating that very high temperatures $\left(>1000{ }^{\circ} \mathrm{C}\right)$ were achieved during the operation of the kiln.

A portable electrical drill with a water-cooled diamond bit was used to sample the limekiln following the standard paleomagnetic procedure. The in situ azimuth and dip of the cores were measured using a compass coupled to a core-orienting fixture with a clinometer. Two sampling areas were selected, both located at the lower part of the cavity. One of them is at the right, in a zone with lots of slag crusts, and there 8 oriented samples were retrieved (labeled R2 to R9) and these are made of very hard slag; the other sampled area is opposite, at the left, and there 12 more samples (labeled L1 to L12) made of a softer material (baked host sediment) were also added to the sample set. Besides, some cylinders that failed to be oriented and additional fragments were kept for archaeointensity measurements (these are mainly R-type samples and are labeled I1 to I8). The obtained cylinders were cut to obtain standard paleomagnetic specimens ( $\sim 2.5 \mathrm{~cm}$ diameter and length); all the samples produced a single specimen.

\section{Archaeomagnetic dating methodology}

Archaeomagnetic dating is an archaeometric technique that measures the natural thermomagnetic remanence (NRM) acquired by baked materials (kiln walls, pottery, hearths, etc.) as these cool down below a blocking temperature. These magnetic data can be correlated to the past values of the Earth's magnetic field. The direction of the NRM should coincide with the local direction of the geomagnetic field prevailing at the time of cooling and, under some circumstances the intensity of NRM is proportional to the strength of the geomagnetic field. The deduced values of the archaeomagnetic direction (declination and inclination) and the intensity can be used either to reconstruct the past evolution of the Earth's magnetic field (if the investigated structure has a wellknown age) or to try to date the investigated structure (if the age of it is not well known). To perform archaeomagnetic dating, the mean values of declination, inclination, and/or intensity are compared with reference curves that describe the local evolution of the Earth's magnetic field. The reference curves that describe the secular variation curve (SVC) of the geomagnetic field were usually defined at a central location but they can also be computed at any desired location using archaeomagnetic models. Both SVC and archaeomagnetic field models are based on compilations of archaeomagnetic data (e.g., Korhonen et al. 2008; Brown et al. 2015). Archaeomagnetic dating is limited to areas where sufficient reference data are available. The first SVC for Iberia was defined at Madrid and was based on 143 archaeomagnetic directions with ages ranging from $775 \mathrm{BC}$ to AD 1959 (Gómez-Paccard et al. 2006b). From 2009, a regional archaeomagnetic model based on spherical cap harmonic analysis has been developed for Europe (Pavón-Carrasco et al. 2009). This model (SCHA.DIF.3k) predicts the evolution of the Earth's magnetic field evolution in Europe and neighboring areas during the last 3000 years. There exists more accurate geomagnetic field global models based on historical records of the magnetic but their time span is restricted to the last 400 years, such as the GUFM1 model (Jackson et al. 2000). This model provides the evolution of the geomagnetic field all over the Earth from 1590 to 1990, and their predictions are based on a collection of historical observations of the magnetic field, particularly from sailors. The SCHA.DIF.3k model has been successfully applied to determine the age of archeological sites in the Tarragona area (e.g., Prevosti et al. 2013; Casas et al. 2014a, 2018), and this model along with the global GUFM1 model has been used to attempt the dating of the limekiln found near the Les Ferreres Roman aqueduct.

\section{Experimental measurements}

Archaeomagnetic measurements were performed using a 755R SRM superconducting rock magnetometer $(2 \mathrm{G}$ Enterprises) and two thermal demagnetizers: an MMTD-80 (Magnetic Measurements) and a TSD-1 (Schönstedt); all the equipment is available at the Paleomagnetism Laboratory (CCiTUB-CSIC) of the Institute of Earth Sciences Jaume Almera (Barcelona, Spain).

\section{Archaeodirection measurements}

Archaeodirections were obtained for each oriented specimen following the standard laboratory protocol that comprises stepwise thermal demagnetization and measurement of the remanent magnetization after each temperature step. Thirteen steps altogether are from 100 to $630{ }^{\circ} \mathrm{C}$. The first heating steps (up to $350{ }^{\circ} \mathrm{C}$ ) were done using the MMTD- 80 demagnetizer, and the remaining steps were done using the TSD-1 demagnetizer that has a lower capacity of samples. The samples were removed from the protocol after the temperature step that produced almost complete demagnetization (>90\% of the initial NRM), and most of the samples were already demagnetized at $570{ }^{\circ} \mathrm{C}$. After each heating step, the magnetic susceptibility was checked using a Geofyzika KLY-2 KappaBridge AC Susceptibility Bridge to be sure that the samples did not suffer important mineralogical variations.

For each specimen, the characteristic remanent magnetization (ChRM) direction was calculated by principal component analyses (Kirschvink 1980) on Zijderveld diagrams (Fig. 2 a-f) using the Plotcore software developed at the University of Liverpool. In three cases, the first values of demagnetization (up to $100{ }^{\circ} \mathrm{C}$ ) were 
Fig. 2 Examples of the obtained Zijderveld plots for every specimen. a and b Typical R-type samples. c and d Typical L-type samples. e Disregarded specimen due to a MAD value $>5$. $\mathbf{f}$ Disregarded specimen considered an outlier. $\mathbf{g}$ At the bottom, the stereographic projection of the archaeomagnetic directions is shown (red dots are disregarded data, and black dots are the data used to compute the obtained mean direction (square) with the corresponding concentric $\alpha_{95}$ error circle)
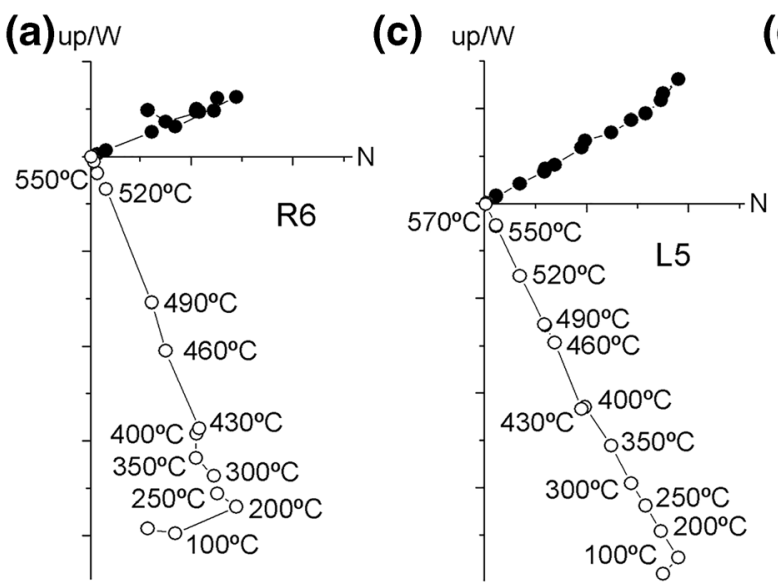

(e)
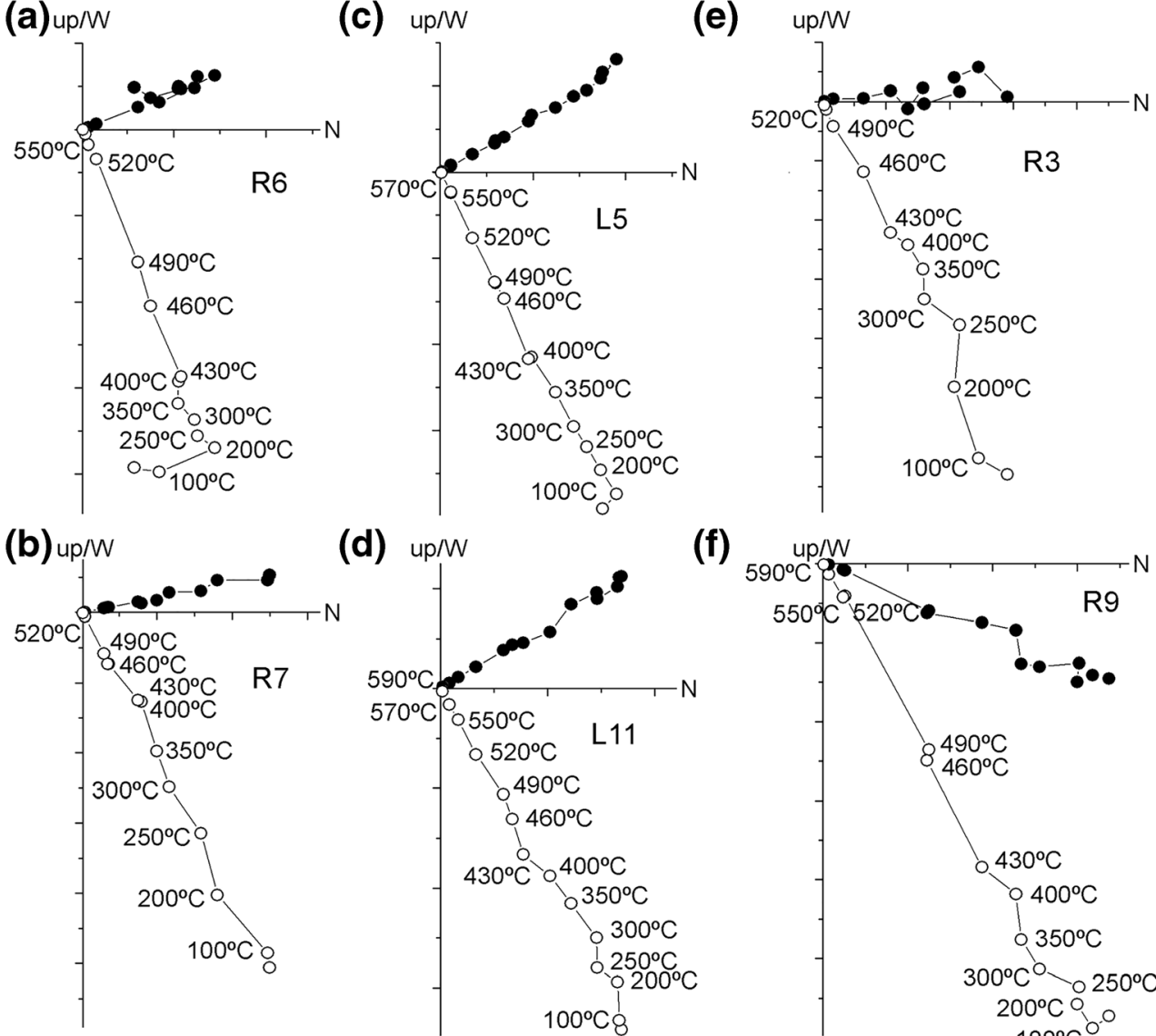

(d)

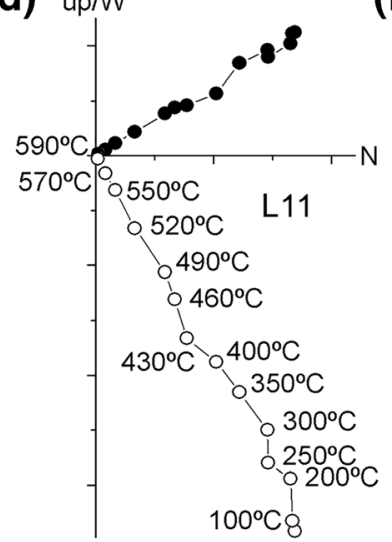

(f)

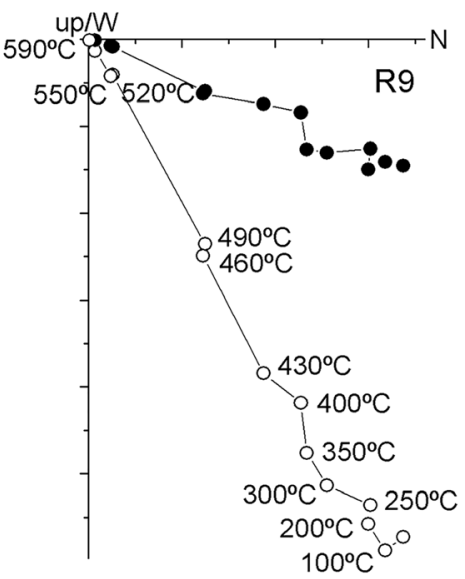

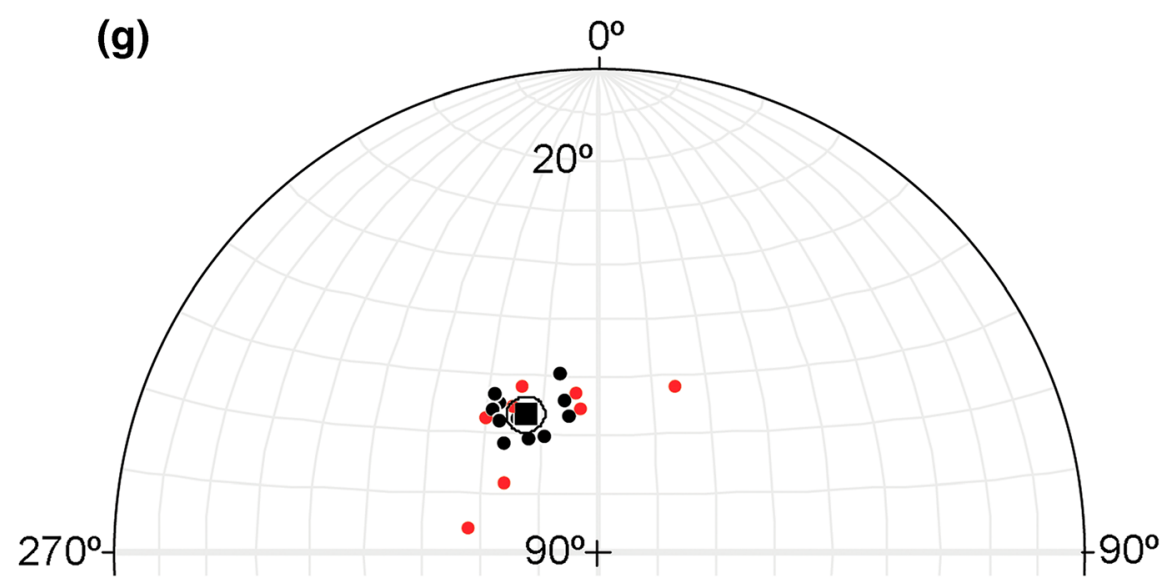

discarded (due to the presence of viscous magnetic components). After optimizing the isolation of the ChRM, the corresponding maximum angular deviation (MAD) was calculated. Specimens with MAD values (not anchoring the mean line to the origin) higher than $5^{\circ}$ were disregarded (see e.g., Fig. 2e) to compute the mean direction of the sampled structure (Hervé et al. 2011). The mean direction was computed following Fisher (Fisher 1953) statistics; concentration parameter $k$ and confidence factor $\alpha_{95}$ were also obtained.

\section{Archaeointensity measurements}

In order to analyze the geomagnetic field intensity of the past, recorded by the studied structure, we studied the 8 non-oriented cylinders mentioned before (labeled as I). Due to their non-regular size, four specimens were packed into salt pellets.

To determine the archaeointensity, we applied the classical Thellier and Thellier method (Thellier and Thellier 1959), recognized in the literature as the best approach to estimate past geomagnetic field strength (see Genevey et al. 2008). 
Experiments were made in air. Eleven (in one case twelve) temperature steps during Thellier experiments were performed between 100 and $510^{\circ} \mathrm{C}\left(570{ }^{\circ} \mathrm{C}\right.$ in one case $)$. At each temperature step, specimens were first heated and cooled applying a laboratory field of $50 \mu \mathrm{T}$ along their $Z$ axis and later they were heated and cooled with the laboratory field applied in the opposite sense. Repeated TRM acquisition steps (pTRM checks) were applied to test for changes in a specimen's ability to acquire TRM (Paterson et al. 2014). These provide a powerful method to detect possible magnetochemical changes during Thellier experiments and therefore were applied every two temperature steps. Moreover, after each cycle of heating-cooling-measurement, the magnetic susceptibility was also checked with the KLY-2 Susceptibility Bridge to detect possible mineralogical changes. The TRM anisotropy upon intensity estimates has been determined at the specimen level by calculating the TRM anisotropy tensor (see Gómez-Paccard et al. 2006a for further details of the methodology used). Unfortunately, cooling rate corrections were not performed due to hints of chemical alteration after the highest temperature steps.

Strict selection criteria similar to those applied in Gómez-Paccard et al. (2006a, 2012) were applied to check the reliability of the determined intensities. The parameter $f$ (Coe 1967), that is the fraction of the initial natural remaining magnetization involved for archaeointensity determinations, has been limited to at least $50 \%$. Only linear NRM-TRM diagrams corresponding to well-defined lines going to the origin in the Zijderveld diagrams have been considered. The MAD, maximum angular deviation (Kirschvink 1980) not anchored to the origin, and the DANG, deviation angle (Pick and Tauxe 1993), were both restricted to a maximum value of $5^{\circ}$. With these restrictions, we retained five archaeointensity determinations and we rejected the results corresponding to three specimens (I3, I4, and I6). In Fig. 3, we show typical examples of the NRM-TRM (Arai) plots obtained together with the respective Zijderveld diagrams of accepted $(a-c)$ and rejected (d) specimens.

It is important to note that, as mentioned before, on this study, we did not estimate in the laboratory the cooling rate dependence of TRM acquisition. This effect, predicted by Néels's theory (Néel 1955), might be important in archaeomagnetic studies since the natural cooling rate followed by archeological samples in the past is typically lower than the cooling rate of laboratory TRM acquisition experiments (of about $1.5 \mathrm{~h}$ ). When not corrected, as in our case, it usually results in overestimated intensity values, sometimes by more than $10 \%$ (Genevey et al. 2008). A reasonable estimation is to apply a mean correction factor of 5\% to the obtained intensity values (Genevey et al. 2008).
Fig. 3 Arai plots after the anisotropy corrections. Imparted heating steps were at $100^{\circ} \mathrm{C}$, $200{ }^{\circ} \mathrm{C}, 250{ }^{\circ} \mathrm{C}, 300^{\circ} \mathrm{C}, 350^{\circ} \mathrm{C}$, $400{ }^{\circ} \mathrm{C}, 430{ }^{\circ} \mathrm{C}, 460{ }^{\circ} \mathrm{C}, 490{ }^{\circ} \mathrm{C}$, $520{ }^{\circ} \mathrm{C}, 550{ }^{\circ} \mathrm{C}, 570{ }^{\circ} \mathrm{C}$ and in some cases also $590^{\circ} \mathrm{C}$ and $610^{\circ} \mathrm{C}$. a-c Accepted specimens following the selection criteria. $\mathbf{d}$ Specimen (I4) rejected because of a distortion of the NRM direction towards the direction of the laboratory field and bad pTRM checks. The intensity of the laboratory field used was $50 \mu \mathrm{T}$ in all cases. The step temperatures used in checking points are indicated. Circles filled correspond to the used points for calculus. In each case, the obtained field strength after the TRM anisotropy correction is indicated (a)

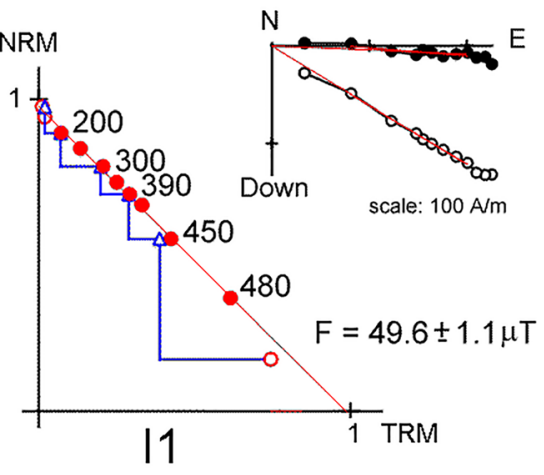

(c)

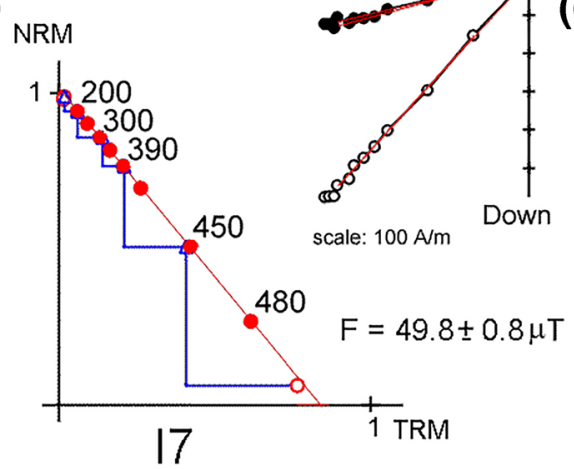

(b)
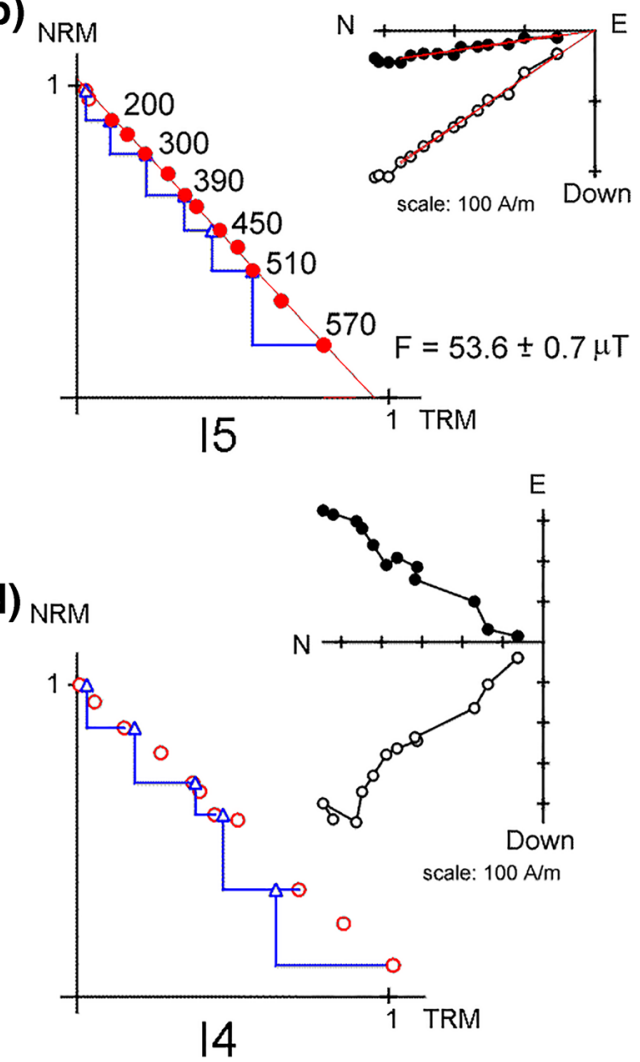


\section{Results}

Table 1 and Fig. $2 \mathrm{~g}$ summarize the archaeodirection results, and the mean direction was computed using 12 specimens from the 20 studied; besides values with MAD $>5^{\circ}$, two outliers were also disregarded: specimen L1 with a strong secondary magnetization that overlaps largely with the original magnetization (see Fig. 2f) and specimen R9 that corresponds to a broken core that was wrongly replaced in its original position to retrieve its orientation. The obtained mean archaeodirection is a declination of $332.3^{\circ}$ and an inclination of $63.7^{\circ}$.

In Table 2, the results of the mean archaeointensities before and after the application of the TRM anisotropy correction are shown along with the values applying a homogeneous cooling rate correction factor of 5\%. The differences between uncorrected and TRM anisotropy corrected intensity values at the specimen level are relatively high (between 2 and $8 \%$ ) and different for each specimen. This confirm, as in Gómez-

Table 1 Measured archaeodirections from specimens sampled at the kiln. Range: temperature range of the heating steps used to compute the ChNRM direction, $D$ archaeomagnetic declination; $I$ archaeomagnetic inclination; $M A D$ maximum angular deviation. Specimens with * were excluded from computation of the mean values due to MAD $>5^{\circ}$, and specimens with $* *$ were outliers also excluded. $k$ and $\alpha_{95}$ are the precision parameter and $95 \%$ confidence limit of the characteristic remanent magnetization, from Fisher statistics. The mean value was calculated using 12 specimens $\left(n_{\mathrm{u}}\right)$

\begin{tabular}{|c|c|c|c|c|c|}
\hline Location & Sample & Range & $D\left(^{\circ}\right)$ & $I\left(^{\circ}\right)$ & MAD \\
\hline \multirow[t]{8}{*}{ Right side } & $\mathrm{R} 2 *$ & - & 352.0 & 62.9 & 5.4 \\
\hline & $\mathrm{R} 3 *$ & - & 353.2 & 65.8 & 5.4 \\
\hline & $\mathrm{R} 4$ & $\mathrm{RT}$ to $550{ }^{\circ} \mathrm{C}$ & 347.7 & 63.6 & 3.8 \\
\hline & $\mathrm{R} 5 *$ & - & 306.6 & 70.7 & 5.9 \\
\hline & R6 & $200-610^{\circ} \mathrm{C}$ & 335.6 & 68.6 & 1.8 \\
\hline & R7 & $\mathrm{RT}$ to $550^{\circ} \mathrm{C}$ & 348.0 & 63.8 & 2.4 \\
\hline & R8 & RT to $570{ }^{\circ} \mathrm{C}$ & 348.1 & 66.7 & 2.8 \\
\hline & $\mathrm{R} 9 * *$ & - & 24.9 & 59.0 & 3.6 \\
\hline \multirow[t]{12}{*}{ Left side } & $\mathrm{L} 1 * *$ & - & 280.4 & 67.8 & 3.4 \\
\hline & $\mathrm{L} 2$ & RT to $590{ }^{\circ} \mathrm{C}$ & 328.9 & 64.7 & 3.1 \\
\hline & L3 & RT to $570{ }^{\circ} \mathrm{C}$ & 329.1 & 63.6 & 2.9 \\
\hline & L4 & RT to $570{ }^{\circ} \mathrm{C}$ & 318.9 & 65.8 & 2.8 \\
\hline & L5 & RT to $590{ }^{\circ} \mathrm{C}$ & 326.9 & 59.6 & 2.8 \\
\hline & L6* & - & 335.9 & 59.2 & 5.3 \\
\hline & L7 & RT to $610{ }^{\circ} \mathrm{C}$ & 323.9 & 60.2 & 4.3 \\
\hline & L8 & $200-610^{\circ} \mathrm{C}$ & 323.5 & 62.4 & 4.0 \\
\hline & L9* & - & 330.1 & 61.7 & 5.6 \\
\hline & L10 & $\mathrm{RT}$ to $610^{\circ} \mathrm{C}$ & 333.5 & 63.1 & 3.1 \\
\hline & L11 & $\mathrm{RT}$ to $570{ }^{\circ} \mathrm{C}$ & 327.1 & 57.9 & 3.7 \\
\hline & L12* & - & 320.0 & 60.6 & 6.5 \\
\hline Mean direction & $K$ & & $D\left(^{\circ}\right)$ & $I\left(^{\circ}\right)$ & $\alpha_{95}\left(^{\circ}\right)$ \\
\hline$n_{\mathrm{u}}=12$ & 223.0 & & 332.2 & 63.7 & 2.9 \\
\hline
\end{tabular}

Paccard et al. (2006b), that this effect has to be studied and corrected separately for each specimen. The final mean value given at the end of the table has been calculated with the weights of Prévot et al. (1985), considering the different quality parameters indicating a mean archaeointensity of $52.2 \mu \mathrm{T}$.

As a first dating attempt, the obtained archaeomagnetic data were compared with the evolution of the geomagnetic field predicted by the regional archaeomagnetic model SCHA.DIF.3k (Pavón-Carrasco et al. 2009); see Fig. 4a. This model allows the computation of reference curves for the interval between $1000 \mathrm{BC}$ and $1900 \mathrm{AD}$ in Europe and neighboring areas. Comparison was performed using a Matlab dating tool developed by Pavón-Carrasco et al. (2011). Introducing as input the experimental declination $(D)$ and inclination $(I)$ values, as well as the associated uncertainty parameter $\alpha_{95}$, the program generates two plots of density of probability of the age and the combined probability resulting from intersection of the two plots, and this is the probability of age that can be used to estimate the age of the sampled structure. In this way, a very narrow probability distribution was obtained indicating that the last heating of the kiln took place in quite recent times (1787 to $1845 \mathrm{AD}$ ) at the $95 \%$ confidence level. This narrow time interval is essentially due to the low declination value of the mean archaeodirection.

Additionally, the measured intensity $(F)$ can also be introduced as input along with the associated standard deviation, and then the estimate of age is produced by combining the three probability distributions $(D, I$, and $F)$. As it is apparent (Fig. 4a), the introduction of the intensity value hardly modifies the probability-of-age distribution (1786 to $1844 \mathrm{AD}$ ).

As all evidence point towards a quite recent age for the last heating, an additional comparison was performed using the GUMF1 model by Jackson et al. (2000); see Fig. 4b. The angular values of the model were assumed to have a standard deviation of $0.5^{\circ}$ (Casas et al. 2014b) and $300 \mathrm{nT}$ for intensity (Linford et al. 2007). However, it should be noted that intensity values could have a higher uncertainty since there are no direct measurements of intensity within the dataset used to compute the model prior to 1840 (Jackson et al. 2000).

Using the GUMF1 model, the age estimation introducing only the directional data ( $D$ and $I$ ) is essentially the same (1789 to $1839 \mathrm{AD}$ ) and again the addition of the measured intensity as input does not modify significantly the obtained dating solution (1787 to 1836 AD) (see Fig. 4b). Dating using SCHA.DIF.3k but constraining the possible age to last 400 years would produce again the same dating solution because SCHA.DIF.3k also integrates available historical observations of the geomagnetic field for this period.

\section{Discussion}

The first question that arises regarding the investigated limekiln is what could be the connection between a limekiln and an 
Table 2 Archaeointensity results for the characteristic components at specimen level. Specimen, name of the specimen studied. Tmin-Tmax interval temperature used for the slope calculation; $N$ number of data points within this temperature interval; $f$ fraction of the NRM component used for the slope calculation; $g$ gap factor; $q$ quality factor; $M A D$ maximum angle of deviation; $D A N G$ deviation angle; $F \pm S D$ mean intensity and standard deviation per specimen without TRM anisotropy correction; $\mathrm{Fe}$, an $\pm S D$ mean intensity and standard deviation per specimen after correction of TRM anisotropy; $\triangle T R M$ mean intensity and standard deviation per specimen after TRM anisotropy and cooling rate corrections; note that the laboratory field of $50 \mu \mathrm{T}$ was applied along the $Z$ axis of the specimens

\begin{tabular}{llrllllllll}
\hline Specimen & $T_{\min }-T_{\max }\left({ }^{\circ} \mathrm{C}\right)$ & \multicolumn{1}{l}{$N$} & $f$ & $g$ & $q$ & $\mathrm{MAD}\left({ }^{\circ}\right)$ & $\mathrm{DANG}\left({ }^{\circ}\right)$ & $\mathrm{F} \pm \mathrm{SD}(\mu \mathrm{T})$ & $\mathrm{Fe}, \mathrm{an} \pm \mathrm{SD}(\mu \mathrm{T})$ & $\mathrm{Fe} \pm \mathrm{SD}(\mu \mathrm{T})(\Delta \mathrm{TRM} 5 \%)$ \\
\hline $\mathrm{I} 1$ & $200-480$ & 8 & 0.55 & 0.8 & 19.8 & 3.5 & 2.1 & $46.0 \pm 0.8$ & $49.6 \pm 1.1$ & $47.1 \pm 1.1$ \\
$\mathrm{I} 2$ & $200-480$ & 8 & 0.62 & 0.76 & 31.7 & 4.4 & 3.3 & $55.8 \pm 0.9$ & $60.9 \pm 0.9$ & $57.9 \pm 0.9$ \\
$\mathrm{I} 5$ & $200-570$ & 11 & 0.71 & 0.89 & 50.3 & 3.0 & 0.8 & $49.8 \pm 0.6$ & $53.6 \pm 0.7$ & $50.9 \pm 0.7$ \\
$\mathrm{I} 7$ & $200-480$ & 8 & 0.67 & 0.77 & 33.9 & 4.9 & 2.0 & $50.8 \pm 0.8$ & $49.8 \pm 0.8$ & $47.3 \pm 0.8$ \\
$\mathrm{I} 8$ & $200-510$ & 9 & 0.94 & 0.77 & 67.5 & 3.0 & 0.8 & $55.4 \pm 0.6$ & $57.3 \pm 0.6$ & $54.4 \pm 0.6$ \\
& & & & & & & & $51.6 \pm 4.1$ & $54.2 \pm 4.9$ & $51.5 \pm 4.6$ \\
\hline
\end{tabular}

aqueduct where the ashlars are stacked without mortar. Investigations undertaken during the last restoration of the Roman aqueduct (Prada et al. 2012) revealed that small quantities of lime mortar were actually used to build the aqueduct. For instance, mortar was used for the foundations of the aqueduct, to start the right and left side of it and to build the specus or water channel (opus signinum). Some of the mortars used as grout are also classified as ancient mortars. In addition, mortar was used in later restorations, presumably in undocumented ancient repairs or in more recent restorations. Among the used mortars, one was extensively used as coating and it would correspond seemingly to the well-documented restoration by Hernández Sanahuja (1854-1856) (Hernández Sanahuja 1867, 1946). The restoration mortars are made of hydraulic and/or non-hydraulic lime mixed with an aggregate made of carbonate fragments and siliceous (schistose and quartzite) fragments including occasional iron-oxide-bearing minerals, possibly from nearby alluvial terraces. Finally, mortars made of Portland cement from the twentieth century were used for occasional repairs during the last 100 years.

The obtained archaeomagnetic ages using the SCHA.DIF.3k model indicate that the sampled limekiln was heated for the last time within the late eighteenth century to the first half of the nineteenth century. The dating solution is a narrow time interval that concentrates at a $95 \%$ of confidence of the probability of age of the kiln, and this time interval has been confirmed using the GUMF1 model. Therefore, the structure can be identified as a modern limekiln on quite solid grounds. The restoration works performed in the nineteenth century would justify the construction of a limekiln next to the aqueduct.

A question that emerges is why the archaeomagnetic dating solution points to an age (1789 to 1836) which is not matching exactly the known age of the restoration (1854 to 1856). A possible answer would be that the kiln was actually used for an earlier restoration. It is known that in 1844, some masonry works were done and removed in the 1854-1856 restoration (Hernández Sanahuja 1946). However, this was possibly a minor repair and we do not know if a mortar was actually used at all. In any case, it is worth noting that the precision of archaeomagnetic dating depends on several factors such as the quality of the data, not only the quality of our data (which are not free of sampling and measuring errors) but also the quality of the data that is used to build the archaeomagnetic field models. Another factor is the rate of change of the geomagnetic field; low rates worsen the highest precision attainable. For Roman sites, archaeomagnetic dating is expected to provide results that are accurate to the nearest century but this can, in principle, improve almost to the nearest year for modern structures (Casas et al. 2018). The increase of the accuracy of archaeomagnetic dating for younger structures is due to the inclusion of historical geomagnetic observations to compute the corresponding geomagnetic models. These observations are mainly from ship logs but include observatory data from mid-nineteenth century onwards. However, directional historical data consists often in individual declination values, inclination was more rarely measured, and intensity was only regularly measured much later. Besides, the existence of historical observations does not guarantee exact predictions by the geomagnetic models; to get the maximal accuracy, these observations should have had to be taken continuously and as close as possible to the structure to be dated. The Ebro Observatory is quite close to the sampled site but magnetic measurements started in the early twentieth century.

It is frequently said that full vector (i.e., adding also the intensity) archaeomagnetic dating provides higher dating accuracy. However, the dating result obtained for the sampled kiln at Les Ferreres site is a time interval of around 50 years and there is almost no difference between dating using only directional data or the full magnetic vector. Actually, dating improvement due to adding intensity data to archaeomagnetic dating using SCHA.DIF.3k model has been demonstrated to be inherently insignificant in most of Europe for the features magnetized in the last 500 years (see video 13 in Casas and Tema (2019)). A similar result would possibly be obtained 
(a) Experimental values vs. SCHA.DIF.3k model
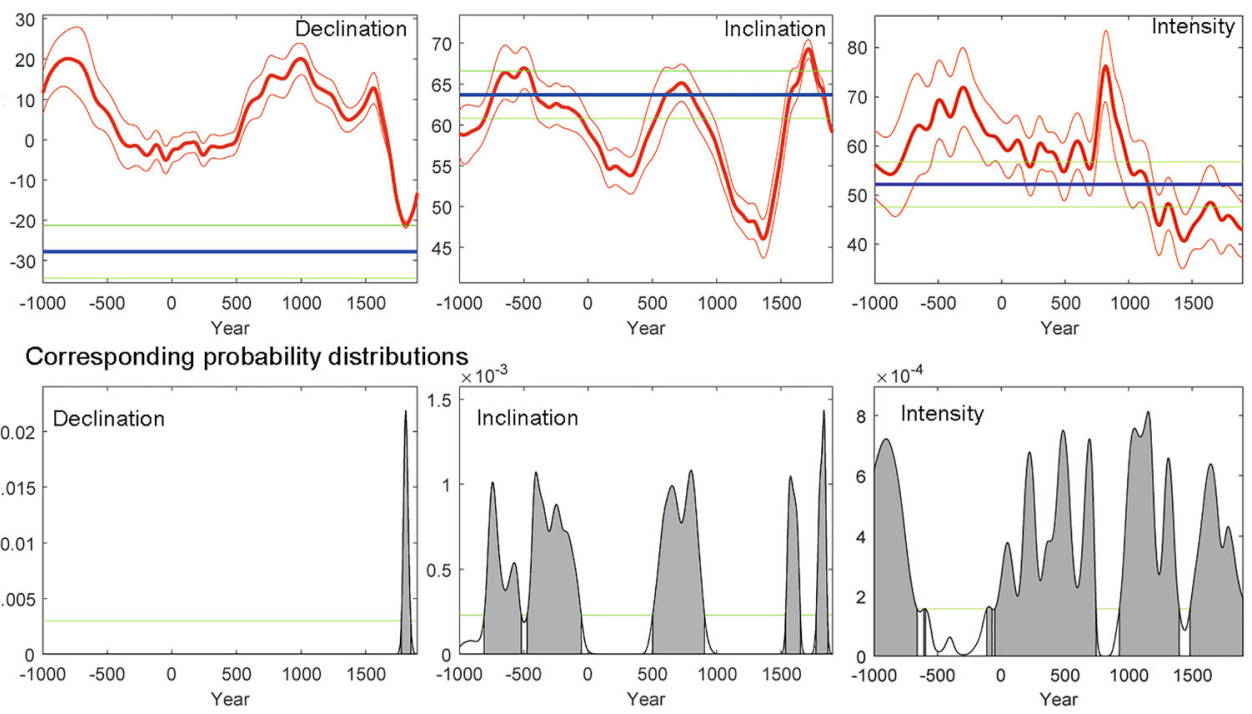

1 Combined probability distributions
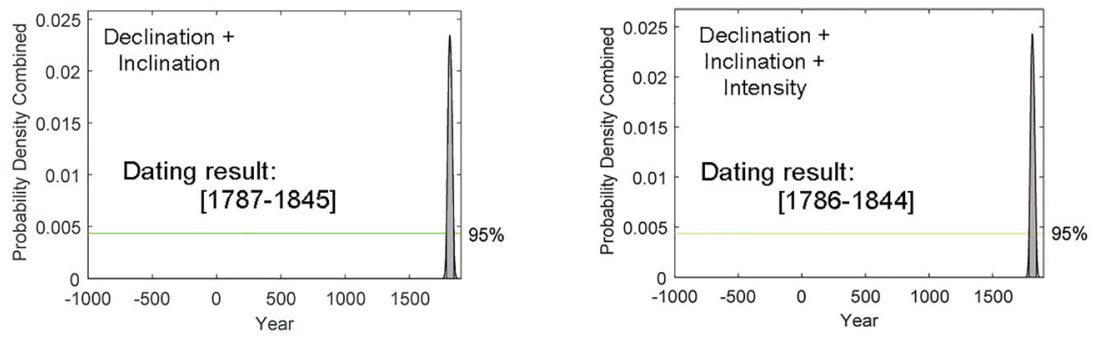

(b) Experimental values vs. GUMF model
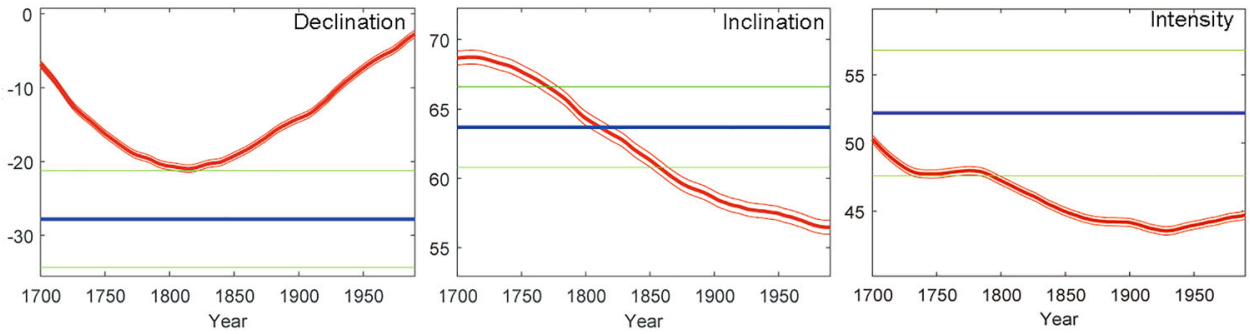

Corresponding probability distributions
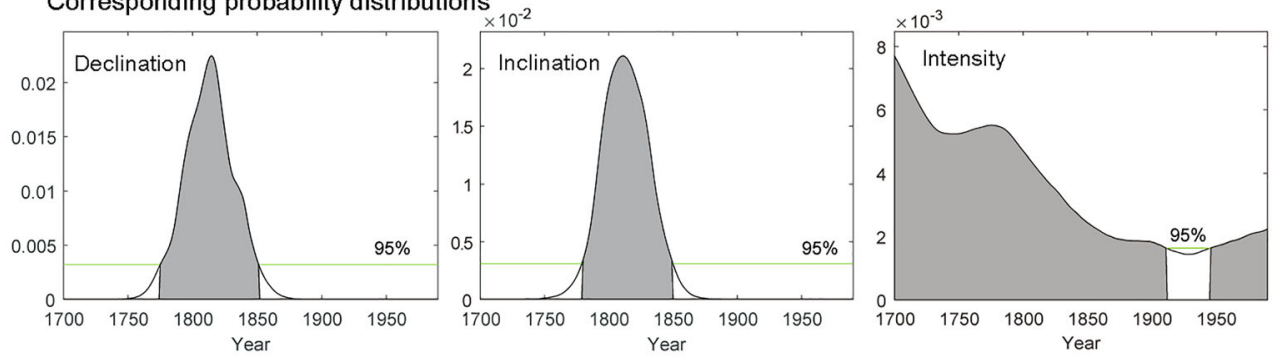

Combined probability distributions
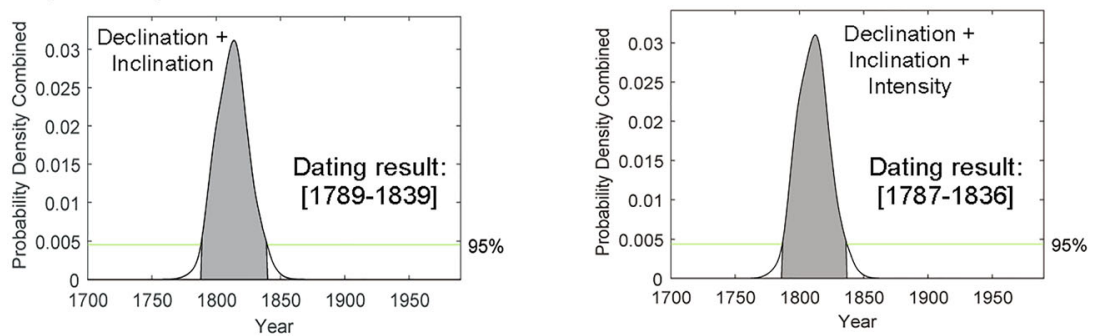
Fig. 4 Probability-of-age density functions obtained with the Matlab tool from Pavón-Carrasco et al. (2011). a Using the SCHA.DIF.3k model. b Using the historical GUMF model

using GUFM1 model. We have assigned a standard deviation of only $300 \mathrm{nT}$ for intensity predictions given by the GUFM1 model. However, the first direct measurement of intensity within the dataset that is behind this model dates from 1840 (Jackson et al. 2000). Possibly, intensity predictions given by the model have a lower accuracy for years $<1840$.

Therefore, the measured archaeointensity, which involves a tedious measuring process, has been of no use. However, a possibility is to keep this measured intensity not as an input to date the structure but as an input to improve archaeointensity databases. The directional data provides a quite constrained age for the limekiln (1787-1845 using the SCHA.DIF.3k model) and this age is consistent with a known restoration of the aqueduct that involved extensive use of lime. Therefore, the measured intensity datum $\left(52.2 \pm 4.6 \mu \mathrm{T}\right.$ at latitude $41.15^{\circ}$ $\mathrm{N}$ and longitude $1.24^{\circ} \mathrm{E}$ ) could be associated with the time period obtained using the corresponding directional data, and this time period could be extended to formally comprise the known years of the restoration by Hernández Sanahuja, resulting in a time period of 69 years (1787-1856).

\section{Conclusions}

We applied archaeomagnetic dating to a limekiln located nearby the Les Ferreres Roman aqueduct in Tarragona (NE Spain), at longitude $1.24^{\circ} \mathrm{E}$ and latitude $41.15^{\circ} \mathrm{N}$. Results indicate that the limekiln is a modern structure linked neither to the original construction of the aqueduct nor to any undocumented ancient restoration. The present study should contribute to establish the importance of the structure as part of the restoration story of the Roman aqueduct.

The SCHA.DIF.3k model provides the evolution of the geomagnetic field during the last 3000 years. By comparing the mean archaeodirection stored in the limekiln walls with SCHA.DIF.3k model, we obtained a time interval within $1787 \mathrm{AD}$ and $1845 \mathrm{AD}$ at $95 \%$ confidence level for the last heating of the kiln. When using the full vector, the obtained time interval is almost the same (1786 AD to 1843 AD). Alternatively, comparison with the GUMF1 model (based on historical records of the geomagnetic field) gives a similar time interval either using only the archaeomagnetic direction (1789 AD to 1839 AD) or the full vector (1787 $\mathrm{AD}$ to $1836 \mathrm{AD})$.

These results are rather consistent with a documented restoration that involved extensive use of a coating mortar. Archaeomagnetic dating models allow dating of burnt structures from archeological sites. The precision of the method depends on the quality of the archaeomagnetic databases. Retrieving archaeomagnetic data from very well-dated structures is the way to improve the archaeomagnetic models and it represents an ongoing collective task. In this sense, the obtained archaeointensity value $(52.2 \pm 4.6 \mu \mathrm{T})$ could be associated with a time interval of 69 years (1787 to 1856) to improve archaeomagnetic intensity datasets.

Acknowledgments The authors would like to thank the Paleomagnetic Laboratory CCiTUB-ICTJA CSIC where the archaeomagnetic measurements were conducted. Thanks to Salvador López for carrying out part of measurements. Dr. Gregg A. Paterson, who reviewed the manuscript, and the editor are also acknowledged for their suggestions.

Funding information This research was funded by the Spanish Ministerio de Economía y Competitividad (project CGL2013-42167-P). MGP also acknowledges the Ramón y Cajal program and the CGL201563888-R (MINECO/FEDER) project of the Spanish Ministerio de Economía y Competitividad. Research by APM was funded by the Beatriu de Pinós postdoctoral program (2017 BP-A 00046), the Consolidated Research group programs (2017SGR00011 and 2017SGR00970) of the Government of Catalonia's Secretariat for Universities and Research of the Ministry of Economy and Knowledge, and R+D project (HAR2017-86509-P) of the Spanish Ministry of Science, Innovation and Universities.

\section{References}

Adell JA, Menchon J (2011) Acueducto Romano. Tarragona. In: Recuperar el Patrimonio, una mirada en profundidad, tomo II. Ministerio de Fomento, Madrid, pp. 20-25

Adie BA (2017) Franchising our heritage: the UNESCO World Heritage brand. Tour Manag Perspect 24:48-53. https://doi.org/10.1016/j. tmp.2017.07.002

Brown MC, Donadini F, Korte M, et al (2015) GEOMAGIA50.v3: 1. general structure and modifications to the archeological and volcanic database Recent advances in environmental magnetism and paleomagnetism. Earth, Planets Sp 67:. https://doi.org/10.1186/ s40623-015-0232-0

Casas L, Tema E (2019) Investigating the expected archaeomagnetic dating precision in Europe: a temporal and spatial analysis based on the SCHA.DIF.3K geomagnetic field model. J Archaeol Sci 108:104972. https://doi.org/10.1016/J.JAS.2019.104972

Casas L, Prevosti M, Fouzai B, Álvarez A (2014a) Archaeomagnetic study and dating at five sites from Catalonia (NE Spain). J Archaeol Sci 41:856-867. https://doi.org/10.1016/j.jas.2013.10.020

Casas L, Ramírez J, Navarro A, Fouzai B, Estop E, Rosell JR (2014b) Archaeometric dating of two limekilns in an industrial heritage site in Calders (Catalonia, NE Spain). J Cult Herit 15:550-556. https:// doi.org/10.1016/j.culher.2013.11.008

Casas L, Auguet C, Cantoni G, Vilar JL, Guasch N, Prevosti M (2018) Using archaeomagnetism to improve the dating of three sites in Catalonia (NE Spain). J Cult Herit 31:152-161. https://doi.org/10. 1016/j.culher.2017.11.004

Coe RS (1967) Paleo-intensities of the Earth's magnetic field determined from Tertiary and Quaternary rockstle. J Geophys Res 72:32473262. https://doi.org/10.1029/JZ072i012p03247

Fisher R (1953) Dispersion on a sphere. Proc R Soc LondonSeries AMathematical Phys Sci 217:295-305. https://doi.org/10.1098/ rspa.1953.0064 
Gaceta de Madrid (1905) Gaceta de Madrid. In: Agencia Estatal Boletín Of. del Estado, Gac. Madrid 102. https://www.boe.es/datos/pdfs/ BOE//1905/102/A00154-00154.pdf

Genevey A, Gallet Y, Constable CG, et al (2008) ArcheoInt: an upgraded compilation of geomagnetic field intensity data for the past ten millennia and its application to the recovery of the past dipole moment. Geochemistry, Geophys Geosystems 9:. https://doi.org/10. 1029/2007GC001881

Gómez-Paccard M, Chauvin A, Lanos P, Thiriot J, Jiménez-Castillo P (2006a) Archeomagnetic study of seven contemporaneous kilns from Murcia (Spain). Phys Earth Planet Inter 157:16-32. https:// doi.org/10.1016/J.PEPI.2006.03.001

Gómez-Paccard M, Chauvin A, Lanos P, McIntosh G, Osete ML, Catanzariti G, Ruiz-Martínez VC, Núñez JI (2006b) First archaeomagnetic secular variation curve for the Iberian Peninsula: comparison with other data from western Europe and with global geomagnetic field models. Geochemistry, Geophys Geosystems 7: Q12001. https://doi.org/10.1029/2006GC001476

Gómez-Paccard M, Chauvin A, Lanos P, Dufresne P, Kovacheva M, Hill MJ, Beamud E, Blain S, Bouvier A, Guibert P (2012) Improving our knowledge of rapid geomagnetic field intensity changes observed in Europe between 200 and 1400 AD. Earth Planet Sci Lett 355-356: 131-143. https://doi.org/10.1016/j.epsl.2012.08.037

Hernández Sanahuja B (1867) El Indicador arqueológico de Tarragona: manual descriptivo de las antigüedades que se conservan en dicha ciudad y sus cercanías, con designación de los puntos donde se encuentran y ruta que debe seguirse para recorrerlos con facilidad. Puigrubi y Aris

Hernández Sanahuja B (1946) Acueducto romano en Tarragona (1857). Boletín Arqueol época IV:16-32

Hervé G, Schnepp E, Chauvin A, Lanos P, Nowaczyk N (2011) Archaeomagnetic results on three Early Iron Age salt-kilns from Moyenvic (France). Geophys J Int 185:144-156. https://doi.org/ 10.1111/j.1365-246X.2011.04933.x

Jackson A, Jonkers ART, Walker MR (2000) Four centuries of geomagnetic secular variation from historical records. Philos Trans R Soc London Ser A-Mathematical Phys Eng Sci 358:957-990. https:// doi.org/10.1098/rsta.2000.0569

Kirschvink JL (1980) The least-squares line and plane and the analysis of palaeomagnetic data. Geophys J Int 62:699-718. https://doi.org/10. 1111/j.1365-246X.1980.tb02601.x

Korhonen K, Donadini F, Riisager P, Pesonen LJ (2008) GEOMAGIA50: an archeointensity database with PHP and MySQL. Geochemistry, Geophys Geosystems 9:n/a-n/a. https:// doi.org/10.1029/2007GC001893
Linford P, Shaw J, Casas L (2007) Archaeomagnetic dating of Dogmersfield Park brick kiln (Southern England). J Archaeol Sci 34:205-213

Macias JM, Rodà I (2015) Tarraco, the first capital. Catalan Hist Rev 8:928. https://doi.org/10.2436/20.1000.01.105

Mar R, Ruiz de Arbulo J, Vivó D, et al (2015) El acueducto de les Ferreres. In: Tarraco. Arquitectura y urbanismo de una capital provincial romana. Volumen II La ciudad imperial. Documents d'Arqueologia Clàssica 6. Universitat Rovira i Virgili, Tarragona, pp 56-59

Néel L (1955) Some theoretical aspects of rock-magnetism. Adv Phys 4: 191-243. https://doi.org/10.1080/00018735500101204

Paterson GA, Tauxe L, Biggin AJ, et al (2014) Standard paleointensity definitions. https://earthref.org/PmagPy/SPD/home.html

Pavón-Carrasco FJ, Osete ML, Torta M, Gaya-Piqué LR (2009) A regional archeomagnetic model for Europe for the last 3000 years, SCHA.DIF.3K: applications to archeomagnetic dating. Geochemistry Geophys Geosystems 10:Q03013. https://doi.org/ 10.1029/2008GC002244

Pavón-Carrasco FJ, Rodríguez-González J, Osete ML, Torta M (2011) A Matlab tool for archaeomagnetic dating. J Archaeol Sci 38:408-419. https://doi.org/10.1016/j.jas.2010.09.021

Pick T, Tauxe L (1993) Holocene paleointensities: Thellier Experiments on submarine basaltic glass from the East Pacific Rise. J Geophys Res Solid Earth 98:17949-17964. https://doi.org/10.1029/ 93JB01160

Prada JL, Guasch N, Badia M (2012) Memòria d'investigació - Informe Final: Diagnòstic geològic i biològic, i de l'estat de conservació de l'aqüeducte romà de Tàrraco

Prevosti M, Casas L, Roig Pérez JF, Fouzai B, Álvarez A, Pitarch À (2013) Archaeological and archaeomagnetic dating at a site from the ager Tarraconensis (Tarragona, Spain): El Vila-sec Roman pottery. J Archaeol Sci 40:2686-2701. https://doi.org/10.1016/j.jas. 2013.01.027

Prévot M, Mankinen EA, Coe RS, Grommé CS (1985) The Steens Mountain (Oregon) geomagnetic polarity transition: 2. Field intensity variations and discussion of reversal models. J Geophys Res Solid Earth 90:10417-10448. https://doi.org/10.1029/ JB090iB12p10417

Thellier E, Thellier O (1959) Sur l'intensité du champ magnétique terrestre dans le passé historique et géologique. Ann Géophysique 15:285-376

Publisher's note Springer Nature remains neutral with regard to jurisdictional claims in published maps and institutional affiliations. 